\title{
Will Women Judges Really Make a Difference?
}

Bertha Wilson

Follow this and additional works at: http://digitalcommons.osgoode.yorku.ca/ohlj Article

\section{Citation Information}

Wilson, Bertha. "Will Women Judges Really Make a Difference?." Osgoode Hall Law Journal 28.3 (1990) : 507-522.

http://digitalcommons.osgoode.yorku.ca/ohlj/vol28/iss3/1 


\title{
WILL WOMEN JUDGES REALLY MAKE A DIFFERENCE? ${ }^{\odot}$
}

\author{
By Madame Justice Bertha Wilson*
}

When I was appointed to the Supreme Court of Canada in the Spring of 1982, a great many women from all across the country telephoned, cabled, or wrote to me rejoicing in my appointment. "Now," they said, "we are represented on Canada's highest court. This is the beginning of a new era for women." So why was $I$ not rejoicing? Why did $I$ not share the tremendous confidence of these women?

First came the realization that no one could live up to the expectations of my well-wishers. I had the sense of being doomed to failure, not because of any excess of humility on my part or any desire to shirk the responsibility of the office, but because I knew from hard experience that the law does not work that way. Change in the law comes slowly and incrementally; that is its nature. It responds to changes in society; it seldom initiates them. And while I was prepared - and, indeed, as a woman judge, anxious - to respond to these changes, $I$ wondered to what extent I would be constrained in my attempts to do so by the nature of judicial office itself.

In the literature which is required reading for every newly appointed judge, it is repeatedly stated that judges must be both independent and impartial, that these qualities are basic to the proper administration of justice and fundamental to the legitimacy of the judicial role. The judge must not approach his or her task

\footnotetext{
${ }^{\circ}$ Copyright, 1990, Madame Justice Bertha Wilson.

* This paper was presented by Madame Justice Wilson at the Fourth Annual Barbara Betcherman Memorial Lecture, Osgoode Hall Law School, 8 Febuary 1990.
} 
with preconceived notions about law or policy, with personal prejudice against parties or issues, or with bias toward a particular outcome of a case. Socrates defined the essential qualities of a judge in the following manner: "Four things belong to a judge: to hear courteously, to answer wisely, to consider soberly, and to decide impartially." 1

In Winters' Handbook for Judges, ${ }^{2}$ there is a section devoted to the essential qualities of a judge; these are defined as integrity and independence, impartiality, flexibility, creativity, responsibility, and common sense. The late Justice Frankfurter was quoted as stating:

To practice the requisite detachment and to achieve sufficient objectivity no doubt demands of judges the habit of self-discipline and self-criticism, incertitude that one's own views are incontestable and alert tolerance toward views not shared. But these are precisely the presuppositions of our judicial process. They are precisely the qualities society has a right to expect from those entrusted with ... judicial power.

In his article "The Virtue of Impartiality," the late Judge Shientag (of the Appellate Division of the New York Supreme Court) discusses the difficulty in attaining impartiality and states that the term implies an appreciation and understanding of the differing attitudes and viewpoints of those involved in a controversy. ${ }^{4} \mathrm{He}$ quotes Lord MacMillan's description of the difficulty judges face in this regard:

The judicial oath of office imposes on the judge a lofty duty of impartiality. But impartiality is not easy of attainment. For a judge does not shed the attributes of common humanity when he assumes the ermine. The ordinary human mind is a mass of prepossessions inherited and acquired, often none the less dangerous because unrecognized by their possessor. Few minds are as neutral as a sheet of plate glass, and indeed a mind of that quality may actually fail in judicial efficiency,

1 J.K. Hoyt, The Cyclopedia of Practical Quotations, rev'd ed. (New York: Funk \& Wagnalls, 1896) at 330.

2 G.R. Winters, ed., Handbook for Judges (The American Judicature Society, 1975).

3 As quoted in L.R. Yankwich, "The Art of Being a Judge" in Winters, ibid. at 4.

${ }^{4}$ B.L. Shientag, "The Virtue of Impartiality" in Winters, ibid. at 57.64. 
for the warmer tints of imagination and sympathy are needed to temper the cold light of reason if human justice is to be done. 5

Later, Lord MacMillan issues the following warning: "[The judge] must purge his mind not only of partiality to persons, but of partiality to arguments, a much more subtle matter, for every legal mind is apt to have an innate susceptibility to particular classes of arguments."

Many have criticised as totally unreal the concept that judges are somehow superhuman, neutral, above politics and unbiased, and are able to completely separate themselves from their personal opinions and predispositions when exercising their judicial function. For example, Lord Justice Scrutton doubted that complete impartiality was possible. He said:

\begin{abstract}
This is rather difficult to attain in any system. I am not speaking of conscious impartiality; but the habits you are trained in, the people with whom you mix, lead to your having a certain class of ideas of such a nature that, when you have to deal with other ideas, you do not give as sound and accurate judgments as you would wish. This is one of the great difficulties at present with Labour. Labour says: "Where are your impartial Judges? They all move in the same circle as the employers, and they are all educated and nursed in the same ideas as the employers. How can a labour man or a trade unionist get impartial justice?" It is very difficult sometimes to be sure that you have put yourself into a thoroughly impartial position between two disputants, one of your own class and one not of your class. Even in matters outside trade-unionist cases ... it is sometimes difficult to be sure, hard as you have tried, that you have put yourself in a perfectly impartial position between the two litigants. ${ }^{7}$
\end{abstract}

In his text, The Politics of the Judiciary, ${ }^{8}$ Professor Griffith caused a furor in legal and judicial circles in the United Kingdom when he questioned whether the English judiciary were capable of impartiality. He stated that for a judge to be completely impartial, he or she would have to be like a political, economic, and social eunuch and have no interests in the world outside the court. Because this is impossible, Griffith concludes that impartiality is an

5 Ibid. at 62.

${ }^{6}$ Ibid.

7 Scrutton L.J., "The Work of the Commercial Courts" (1921) 1 Camb. L.J. 6 at 8.

8 J.A.G. Griffith, The Politics of the Judiciary (Manchester: Manchester University Press, 1977). 
ideal incapable of realization. ${ }^{9}$ He says of the English judiciary: "These judges have by their education and training and the pursuit of their profession as barristers, acquired a strikingly homogeneous collection of attitudes, beliefs and principles, which to them represents the public interest." ${ }^{110}$ The public interest, in other words, is perceived from the viewpoint of their own class. Chief Justice Nemetz has suggested that Professor Griffith's views may have some validity in Canada too, more particularly, Professor Griffith's view that judicial attitudes towards political and social issues reflect the lack of a proper understanding of the view of labour unions, minorities, and the underprivileged. ${ }^{11}$

Judge Rosalie Abella (Chair of the Ontario Law Reform Commission) also doubts that judicial impartiality is a realistic requirement. In her article "The Dynamic Nature of Equality," she emphasizes that "[e]very decisionmaker who walks into a courtroom to hear a case is armed not only with the relevant legal texts, but with a set of values, experiences and assumptions that are thoroughly embedded." 12

Judge Shientag refers to the fact that many judges believe that they have acted with the cold neutrality of an impartial judge when, in fact, they have completely failed to examine their prejudices and biases. He points out that the partiality and prejudice with which we are concerned is not overt, not something tangible on which the judge can put his or her finger. Yet by failing to appreciate this, many judges are lulled into a false sense of security. ${ }^{13}$ Judge Shientag emphasizes that progress will be made only when judges recognize this condition as part of the weakness of human nature. Then, "[h]aving admitted the liability to prejudice, unconscious for the most part, subtle and nebulous at times, the next

9 Ibid. at $189-92$.

10 Ibid. at 193.

11 Nemetz C.J.B.C., "The Concept of an Independent Judiciary" (1986) 20 U.B.C. L. Rev. 286 at 290.

12 R.S. Abella, "The Dynamic Nature of Equality" in S. Martin \& $\mathrm{K}$ Mahoney, eds, Equality and Judicial Neutrality (Toronto: Carswell, 1987) 3 at 8-9.

13 Shientag, supra, note 4 at 57. 
step is to determine what the judge, with his trained mind, can do to neutralize the incessant play of these obscure yet potent influences." ${ }^{14}$ Judge Shientag concludes that

the judge who realizes, before listening to a case, that all men have a natural bias of mind and that thought is apt to be coloured by predilection, is more likely to make a conscientious effort at impartiality and dispassionateness than one who believes that his elevation to the bench makes him at once the dehumanized instrument of infallible logical truth. 15

But what has all this got to do with the subject: "Will women judges really make a difference?" It has a great deal to do with it, and whether you agree or not will probably depend on your perception of the degree to which the existing law reflects the judicial neutrality or impartiality we have been discussing. If the existing law can be viewed as the product of judicial neutrality or impartiality, even although the judiciary has been very substantially male, then you may conclude that the advent of increased numbers of women judges should make no difference, assuming, that is, that these women judges will bring to bear the same neutrality and impartiality. However, if you conclude that the existing law, in some areas at least, cannot be viewed as the product of judicial neutrality, then your answer may be very different.

Two law professors at New York University, Professor John Johnston and Professor Charles Knapp, have concluded, as a result of their studies of judicial attitudes reflected in the decisions of judges in the United States, that United States judges have succeeded in their conscious efforts to free themselves from habits of stereotypical thought with regard to discrimination based on colour. ${ }^{16}$ However, they were unable to reach a similar conclusion with respect to discrimination based on sex, finding that American judges had failed to bring to sex discrimination the judicial virtues of detachment, reflection, and critical analysis which had served them so well with respect to other areas of discrimination. They state: "'Sexism' - the making of unjustified (or at least unsupported)

14 Ibid. at 58.

15 Ibid.

16 J.D. Johnston \& C.L. Knapp, "Sex Discrimination by Law: A Study in Judicial Perspective" (1976) 46 N.Y.U. L. Rev. 675. 
assumptions about individual capabilities, interests, goals and social roles solely on the basis of sex differences - is as easily discernible in contemporary judicial opinions as racism ever was."17

Professor Norma Wikler, a sociologist at the University of California, has reviewed a number of other studies of judicial attitudes conducted by legal researchers and social scientists. These studies confirm that male judges tend to adhere to traditional values and beliefs about the natures of men and women and their proper roles in society. The studies show overwhelming evidence that gender-based myths, biases, and stereotypes are deeply embedded in the attitudes of many male judges, as well as in the law itself. Researchers have concluded that gender difference has been a significant factor in judicial decision-making, particularly in the areas of tort law, criminal law, and family law. Further, many have concluded that sexism is the unarticulated underlying premise of many judgments in these areas, and that this is not really surprising having regard to the nature of the society in which the judges themselves have been socialized. ${ }^{18}$

A number of strategies have been tried in the United States to eliminate gender bias from the courts - legislative reform, enhanced legal representation of women litigants, increased numbers of women lawyers and judges. These measures have been accompanied by an intensive educational program aimed at judges right across the country. Women judges and women lawyers in the United States played a very active role in the creation of this program. They were able to persuade substantial numbers of their male peers that gender bias, like all other forms of bias they had worked so hard to eradicate, violated the core principle of judicial impartiality and neutrality and posed an increasing threat in the 1970s and 1980s to the maintenance of public confidence in the judiciary.

As might be anticipated, a direct frontal attack on gender bias in the courts, and especially the institution of an educational program for judges on this subject, was highly controversial. It

\footnotetext{
17 Ibid. at 676.

18 N.J. Wikler, "On the Judicial Agenda for the 80s: Equal Treatment for Men and Women in the Courts" (1980) 64 Jud. 202.
} 
would probably have died on the vine but for the support of a substantial number of the country's leading male judges and educators who recognized that profound changes were taking place in society, including a major redefinition of the roles of men and women.

Professor Wikler has been one of the moving forces behind the United States program to sensitize judges to the problem of gender bias. She reports some modest indicators of success of the program, although she acknowledges that it is too early to assess the long-term effects. She reports that requests for speakers and material generated from courses and workshops indicate a growing interest in the program, as does the positive evaluation by judges themselves of the courses presented. Even more gratifying, attorneys practising in states where the program has been actively promoted report a noticeable increase in judicial sensitivity to gender bias. Program materials have been cited in the courts and quoted in the judgments. Judicial conduct commissions are disciplining judges for gender biased behaviour, such as sexist remarks to women lawyers and litigants and inappropriate comments in rape cases. Professor Wikler concludes that one very important goal has been achieved: gender bias is now a subject which judges and judicial educators think and care about. ${ }^{19}$

Another development in the United States has been the establishment of judicially appointed task forces to investigate the extent to which gender bias exists in the judiciary. The first of these task forces was created in New Jersey in 1982. As stated by Chief Justice Wilentz, it was mandated to "investigate the extent to which gender bias exists in the New Jersey judicial branch, and to develop an educational program to eliminate any such bias." ${ }^{20}$ Since 1982, over twenty other states have created task forces. In her article "The Success of the American Program," Lynn Hecht Schafran reports that the task forces have "significantly enhanced judicial

${ }^{19}$ N.J. Wikler, "Identifying and Correcting Judicial Gender Bias" in Martin \& Mahoney, supra, note 12 at 12 .

20 As quoted in L.H. Schafran, "The Success of the American Program" in Martin \& Mahoney, ibid. at 412. 
education programs and created a level of public awareness that generates its own pressures for reform."21

Schafran identifies four reasons why a judicially appointed task force is important, as opposed to other groups outside the court system focussing on particular concerns. First, a gender bias task force is able to look at a broad range of issues and demonstrate a pattern of gender bias that manifests itself throughout the judicial system. The second reason concerns credibility. Schafran explains this critical reason in the following manner:

\begin{abstract}
When a coalition of rape crisis counsellors asserts that rape victims are ill treated in court, or a women's bar association claims that women attorneys are denied a fair share of appointments to challenging and lucrative civil and criminal cases, these charges are heard as the claims of special interest groups. When a blue ribbon panel appointed by a state's chief justice makes these same charges, people listen. There was little in what the New Jersey and New York Task Forces reported that numerous women's rights organization and feminist legal commentators have not been saying for years, but the task force reports twice made the front page of the New York Times. 22
\end{abstract}

The third reason relates to the administration of the task force. The Chief Justice of the state is in a position to authorize funds, compel co-operation, endorse and propose reforms and ensure their implementation, and support judicial education on the subject. Finally, a task force brings together judges, lawyers, law professors, and community activists to study an issue which many of them do not initially appreciate is an issue at all. Schafran reports that task force members from New Jersey and New York "who start out with no knowledge of gender bias in the courts, or even a conviction that the idea is nonsense, emerge from the data collection process convinced that the problem is real and has deeply serious implications for the administration of justice."23

So, where do we stand in Canada on this matter? As might be expected, feminist scholars in Canada have over the past two decades produced a vast quantity of literature on the subject, some of it very insightful, very balanced, and very useful, and some of it very radical, quite provocative, and probably less useful as a result.

\footnotetext{
21 Ibid. at 412-13.

22 Ibid. at 413-14.

23 Ibid. at 414.
} 
But all of it, it seems, is premised, at least as far as judicial decisionmaking is concerned, on two basic propositions: one, that women view the world and what goes on in it from a different perspective from men; and two, that women judges, by bringing that perspective to bear on the cases they hear, can play a major role in introducing judicial neutrality and impartiality into the justice system.

Taking from my own experience as a judge of fourteen years' standing, working closely with my male colleagues on the bench, there are probably whole areas of the law on which there is no uniquely feminine perspective. This is not to say that the development of the law in these areas has not been influenced by the fact that lawyers and judges have all been men. Rather, the principles and the underlying premises are so firmly entrenched and so fundamentally sound that no good would be achieved by attempting to re-invent the wheel, even if the revised version did have a few more spokes in it. I have in mind areas such as the law of contract, the law of real property, and the law applicable to corporations. In some other areas of the law, however, a distinctly male perspective is clearly discernible. It has resulted in legal principles that are not fundamentally sound and that should be revisited when the opportunity presents itself. Canadian feminist scholarship has done an excellent job of identifying those areas and making suggestions for reform. Some aspects of the criminal law in particular cry out for change; they are based on presuppositions about the nature of women and women's sexuality that, in this day and age, are little short of ludicrous.

But how do we handle the problem that women judges, just as much as their male counterparts, are subject to the duty of impartiality? As was said at the outset, judges must not approach their task with preconceived notions about law and policy. They must approach it with detachment and, as Lord MacMillan said, purge their minds "not only of partiality to persons, but of partiality to arguments." 24 Does this then foreclose any kind of "judicial affirmative action" to counteract the influence of the dominant male perspective of the past and establish judicial neutrality through a countervailing female perspective? Is Karen Selick, writing recently

${ }^{24}$ Shientag, supra, note 4 at 62 . 
in the Lawyers Weekly, correct when she argues that offsetting male bias with female bias would only be compounding the injustice? ${ }^{25}$ Does the nature of the judicial process itself present an insuperable hurdle so that the legislatures rather than the courts must be looked to for any significant legal change?

In part this may be so. Certainly, the legislature is the more effective instrument for rapid or radical change. But there is no reason why the judiciary cannot exercise some modest degree of creativity in areas where modern insights and life's experience have indicated that the law has gone awry. However, and this is extremely important, it will be a Pyrrhic victory for women and for the justice system as a whole if changes in the law come only through the efforts of women lawyers and women judges. The Americans were smart to realize that courses and workshops on gender bias for judges, male and female, are an essential follow-up to scholarly research and learned writing. In Canada, we are just beginning to touch the fringes.

The first national, interdisciplinary conference on the relationship between judicial neutrality and gender equality was held in Banff, Alberta in May 1986. At the conference, judges, academics, practising lawyers, and experts in anthropology, political science, sociology, and social welfare examined judicial behaviour in equality related matters. The judicial acceptance of traditional stereotypes concerning women was noted, as well as its impact in Canada on important areas of constitutional equality litigation, family law, criminal law, tort law, and human rights. ${ }^{26}$

Mr. Justice Rothman of the Quebec Court of Appeal, one of the speakers at the conference, endorsed the approach adopted in the United States to counteract gender bias through nation-wide educational programs for judges and the creation of judicial task forces. In his perception, women face the same kind of discrimination in Canada as they do in the United States, and we should be working to change the old attitudes now. He suggested that conferences and seminars for newly appointed judges would be

${ }^{25}$ K. Selick, "Adding More Women Won't End Bias in Justice System" (1990) 9:35 Lawyer's Weekly 7 at 7.

26 "Preface" in Martin \& Mahoney, supra, note 12 at iii-iv. 
a good place to start, but in addition, courses on gender bias should be part of the continuing education programs for judges at all stages of their careers. Justice Rothman added that it is not going to be enough to sensitize judges to equality issues if lawyers are not sensitized to them as well. ${ }^{27}$

The Canadian Judicial Council and the Canadian Judicial Centre have both recognized the need for judicial education in this area and will include gender issues in their summer seminars for judges this year. I understand that the Centre hopes to subsequently present the program in a number of locations across the country, and the course materials will be available to all Canadian judges. I heartily endorse this initiative. It is a significant first step towards the achievement of true judicial neutrality. But it is only a first step and there is a long way to go.

I return, then, to the question of whether the appointment of more women judges will make a difference. Because the entry of women into the judiciary is so recent, few studies have been done on the subject. Current statistics show that just over 9 percent of federally appointed judges are women ${ }^{28}$ it is reasonable to assume that more women will be appointed to the Bench as more women become licensed to practice law. Will this growing number of women judges by itself make a difference?

The expectation is that it will, that the mere presence of women on the bench will make a difference. In her article "The Gender of Judges," Suzanna Sherry (an Associate Law Professor at the University of Minnesota) suggests that the mere fact that women are judges serves an educative function; it helps to shatter stereotypes about the role of women in society that are held by male judges and lawyers, as well as by litigants, jurors, and witnesses. ${ }^{29}$

Judge Gladys Kessler (former President of the National Association of Women Judges in the United States) defends the search for competent women appointees to the bench. She says:

27 M.L. Rothman, "Prospects for Change in Canada: Education for Judges and Lawyers" in Martin \& Mahoney, ibid. at 421-27.

${ }^{28}$ Canadian Centre for Justice Statistics, Profile of Courts in Canada, 1987-1988 (Ottawa: Supply and Services Canada, 1989).

29 S. Sherry, "The Gender of Judges" (1986) 4 Law \& Inequality 159 at 160. 
"But the ultimate justification for deliberately seeking judges of both sexes and all colors and backgrounds is to keep the public's trust. The public must perceive its judges as fair, impartial and representative of the diversity of those who are being judged. ${ }^{130}$ Justice Wald has expressed similar sentiments. She believes that women judges are indispensable to the public's confidence in the ability of the courts to respond to the legal problems of all classes of citizens. ${ }^{31}$

Dianne Martin, a criminal lawyer writing in the Lawyers Weekly, sees another way in which the presence of women on the bench is helpful and constructive. It is easier, she says, for women lawyers to appear as counsel before a woman judge. She says the "difference is that you are 'normal' - you and the judge have certain shared experiences and a shared reality that removes, to a certain extent, the need to 'translate' your submissions into 'man talk' or a context that a male judge will understand." ${ }^{132}$ The woman judge does not see you as "out of place" or having "something to prove by appearing in a courtroom arguing a case before her."133

For women counsel, appearing in front of a woman judge also decreases the risk of sexist comments and inappropriate efforts at humour. The courtroom treatment of women litigants, witnesses, and lawyers was examined by the New Jersey and New York task forces. The New York Task Force on Women in the Courts found that "[w]omen uniquely, disproportionately, and with unacceptable frequency must endure a climate of condescension, indifference, and hostility. ${ }^{134}$ The New Jersey Supreme Court Task Force on Women in the Courts found strong evidence that women are often treated differently in courtrooms, in judges' chambers, and at professional

30 As quoted in J.E. Scott, "Women on the Illinois State Court Bench" (1986) 74 Ill. B.J. 436 at 438.

31 P.M. Wald, "Women in the Law" (1988) 24:11 Trial 75 at 80.

32 D. Martin, "Have Women Judges Really Made a Difference?" (1986) 6:14 Lawyers Weekly 5 at 5.

33 Ibid.

34 Schafran, supra, note 20 at 419. 
gatherings. ${ }^{35}$ As Justice Rothman pointed out at the Banff conference, there is "no possible excuse for a judge allowing himself or anyone else in his courtroom to make unprofessional or inappropriate references to gender." He saw as a possible solution the appointment of more women judges and more courteous and sensitive male judges. ${ }^{36}$

Some feminist writers are persuaded that the appointment of more women judges will have an impact on the process of judicial decision-making itself and on the development of the substantive law. As was mentioned earlier, this flows from the belief that women view the world and what goes on in it from a different perspective from men. Some define the difference in perspective solely in terms that women do not accept male perceptions and interpretations of events as the norm or as objective reality. Carol Gilligan (a Professor of Education at Harvard University) sees the difference as going much deeper than that. In her view, women think differently from men, particularly in responding to moral dilemmas. They have, she says, different ways of thinking about themselves and their relationships to others. ${ }^{37}$

In her book In a Different Voice, ${ }^{38}$ Gilligan analyses data she collected, in the form of responses from male and female participants, in a number of different studies. These responses, she submits, support her central thesis that women see themselves as essentially connected to others and as members of a community; men see themselves as essentially autonomous and independent of others. Gilligan makes no claim about the origins of the differences she describes. She does, however, use the psychoanalytical work of Dr. Nancy Chodorow as a starting point. ${ }^{39}$ Chodorow postulates that gender differences arise from the fact that women do the mothering of children. Because the gender identity of male children is not the

\section{Ibid. at 415.}

36 Rothman, supra, note 27 at 427.

37 See C. Gilligan, In a Different Voice: Psychological Theory and Women's Development (Cambridge, Mass.: Harvard University Press, 1982).

38 Ibid.

39 Ibid. at 8. 
same as their mothers, they tend to distance and separate themselves from their mothers' female characteristics in order to develop their masculinity. Female children, on the other hand, define themselves through attachment to their mothers. ${ }^{40}$ Masculinity is therefore, according to Giligan, defined through separation and individualism; femininity is defined through attachment and the formation of relationships. The gender identity of the male, she submits, is threatened by relationships; the gender identity of the female is threatened by separation. ${ }^{41}$

Gilligan's work on conceptions of morality among adults suggests that women's ethical sense is significantly different from men's. Men see moral problems as arising from competing rights; the adversarial process comes easily to them. Women see moral problems as arising from competing obligations, the one to the other; the important thing is to preserve relationships, to develop an ethic of caring. The goal, according to women's ethical sense, is not seen in terms of winning or losing but, rather, in terms of achieving an optimum outcome for all individuals involved in the moral dilemma. ${ }^{42}$ It is not difficult to see how this contrast in thinking might form the basis of different perceptions of justice.

There is merit in Gilligan's analysis. In part, it may explain the traditional reluctance of courts to get too deeply into the circumstances of a case, their anxiety to reduce the context of the dispute to its bare bones through a complex system of exclusionary evidentiary rules. This is one of the characteristic features of the adversarial process. We are all familiar with the witness on crossexamination who wants to explain his or her answer, who feels that a simple yes or no is not an adequate response, and who is frustrated and angry at being cut off with a half-truth. It is so much easier to come up with a black and white answer if you are unencumbered by a broader context which might prompt you, in

\footnotetext{
40 N. Chodorow, The Reproduction of Mothering: Psychoanalysis and the Sociology of Gender (Berkeley: University of California Press, 1978) at 91, 167-70.

41 Gilligan, supra, note 37 at 8.

42 See, for example, ibid. at 16-18, 24-32, 163-65.
} 
Lord MacMillan's words, to temper the cold light of reason with the warmer tints of imagination and sympathy. ${ }^{43}$

Gilligan's analysis may also explain the hostility of some male judges to permitting intervenors in human rights cases. The main purpose of having intervenors is to broaden the context of the dispute, to show the issue in a larger perspective or as impacting on other groups not directly involved in the litigation at all. But it certainly does complicate the issues to have them presented in polycentric terms.

Professor Patricia Cain, in her article "Good and Bad Bias: A Comment on Feminist Theory and Judging," says:

\begin{abstract}
What we want, it seems to me, are lawyers who can tell their clients' story, lawyers who can help judges to see the parties as human beings, and who can help remove the separation between judge and litigant. And, then, what we want from our judges is a special ability to listen with connection before engaging in the separation that accompanies judgment. ${ }^{44}$
\end{abstract}

Obviously, this is not an easy role for the judge - to enter into the skin of the litigant and make his or her experience part of your experience and only when you have done that, to judge. But we have to do it; or at least make an earnest attempt to do it. Whether the criticism of the justice system comes to us through Royal Commissions, through the media, or just through our own personal friends, we cannot escape the conclusion that, in some respects, our existing system of justice has been found wanting. And as Mr. Justice Rothman says, the time to do something about it is now.

One of the important conclusions emerging from the Council of Europe's Seminar on Equality between Men and Women held in Strasbourg last November is that the universalist doctrine of human rights must include a realistic concept of masculine and feminine humanity regarded as a whole, that human kind is dual and must be represented in its dual form if the trap of an asexual abstraction in which human being is always declined in the masculine is to be

43 Supra, note 4 at 62 .

44 P.A. Cain, "Good and Bad Bias: A Comment on Feminist Theory and Judging" (1988) 61 S. Cal. L. Rev. 1945 at 1954. 
avoided. ${ }^{45}$ If women lawyers and women judges through their differing perspectives on life can bring a new humanity to bear on the decision-making process, perhaps they will make a difference. Perhaps they will succeed in infusing the law with an understanding of what it means to be fully human.

45 Council of Europe, Committee on Equality between Men and Women, The Democratic Principle of Equal Representation - Forty Years of Council of Europe Activity (Seminar, Strasbourg, 6-7 November 1989). 